\title{
PENGARUH CORPORATE GOVERNANCE DAN STRUKTUR KEPEMILIKAN TERHADAP KINERJA KEUANGAN PERUSAHAAN
}

\author{
Muhammad Saifi \\ Fakultas Ilmu Administrasi Universitas Brawijaya \\ E-mail : $\underline{\text { msaifi@ub.ac.id }}$
}

\begin{abstract}
This study examines the effect of corporate governance and ownership structure on the company's financial performance. Good corporate governance is proxyed by the proportion of independent commissioners, while the ownership structure is proxyed by the proportion of institutional and managerial ownership. Financial performance indicators are measured by Return on Equity (ROE) and Return on Assets (ROA). The sample used was 22 companies from a population of 54 property companies and public real estate that were publicly traded on the Indonesia Stock Exchange and obtained a total of 110 observations for the period 2011-2015. The sample is determined using the purposive sampling method. This study uses multiple regression analysis and is processed using SPSS. The results showed that there was a significant negative effect between the proportion of independent commissioners and institutional ownership of financial performance as measured by ROE. However, managerial ownership was found not to have a significant effect on financial performance as measured by ROE. Other results indicate that the proportion of independent commissioners, institutional ownership, and managerial ownership has a positive and significant effect on financial performance measured using ROA.
\end{abstract}

Keywords: Corporate Governance, Ownership Structure, Corporate Financial Performance

\begin{abstract}
ABSTRAK
Penelitian ini menguji pengaruh corporate governance dan struktur kepemilikan terhadap kinerja keuangan perusahaan. Good corporate governance diproxy dengan proporsi dewan komisaris independen, sedangkan struktur kepemilikan diproxy dengan proporsi kepemilikan institusional dan manajerial. Indikator kinerja keuangan diukur dengan Return on Equity (ROE) dan Return on Asset (ROA). Sampel yang digunakan adalah 22 perusahaan dari populasi 54 perusahaan properti dan real estate yang go-public di Bursa Efek Indonesia dan didapatkan total 110 pengamatan untuk periode 2011-2015. Sampel ditentukan dengan menggunakan metode purposive sampling. Penelitian ini menggunakan analisis regresi berganda dan diolah menggunakan SPSS. Hasil penelitian menunjukkan bahwa terdapat pengaruh yang negatif signifikan antara proporsi dewan komisaris independen dan kepemilikan institusional terhadap kinerja keuangan yang diukur dengan ROE. Namun, kepemilikan manajerial ditemukan tidak memiliki pengaruh yang signifikan terhadap kinerja keuangan yang diukur dengan ROE. Hasil lain menunjukkan bahwa proporsi dewan komisaris independen, kepemilikan institusional, dan kepemilikan manajerial berpengaruh positif dan signifikan terhadap kinerja keuangan yang diukur menggunakan ROA.
\end{abstract}

Kata Kunci : Corporate Governance, Struktur Kepemilikan , Kinerja Keuangan Perusahaan 


\section{PENDAHULUAN}

Pentingnya penerapan sistem tata kelola perusahaan yang baik (Good Corporate Governance) masih menjadi fokus utama dalam pengembangan iklim usaha di Indonesia terutama dalam rangka mendorong pertumbuhan ekonomi. Good Corporate Governance (GCG) dipandang sebagai salah satu kunci sukses perusahaan untuk tumbuh secara berkelanjutan, sekaligus memenangkan persaingan bisnis global terutama bagi perusahaan terbuka. Tim studi BAPEPAMLK yang melakukan pengkajian penerapan prinsip-prinsip OECD 2004 dalam peraturan Bapepam mengenai corporate governance menemukan bahwa pengembangan GCG dianggap penting karena krisis ekonomi dunia di kawasan Asia dan Amerika Latin yang diyakini muncul karena kegagalan penerapan GCG seperti sistem regulatory yang kurang baik, standar akuntansi dan audit yang tidak konsisten, serta Board of Directors (BOD) yang kurang peduli terhadap hakhak pemegang saham minoritas.

Di hampir semua negara termasuk Indonesia, sektor industri properti dan realestate merupakan sektor dengan karakteristik yang sulit untuk diprediksi dan berisiko tinggi. Pasang surut sektor ini memiliki amplitudo yang besar, yaitu pada saat terjadi pertumbuhan ekonomi yang tinggi, industri properti dan realestate mengalami booming dan cenderung over supplied, namun sebaliknya pada saat pertumbuhan ekonomi mengalami penurunan, secara cepat sektor ini akan mengalami penurunan yang cukup drastis pula. Industri sektor properti dan realestate dikatakan juga mengandung risiko tinggi. Hal ini disebabkan pembiayaan atau sumber dana utama sektor ini pada umumnya diperoleh melalui kredit perbankan, sementara sektor ini beroperasi dengan menggunakan aktiva tetap berupa tanah dan bangunan. Meskipun tanah dan bangunan dapat digunakan untuk melunasi utang tetapi aktiva tersebut tidak dapat dikonversikan ke dalam kas dalam waktu yang singkat. Oleh karena itu, banyak pengembang (developer) tidak dapat melunasi utangnya pada waktu yang telah ditentukan (Mulviawan, 2012). Sebagai instrumen investasi, properti dianggap menarik karena tingkat likuiditasnya moderat, namun imbal hasil return dan capital gain per tahun rata-rata cukup tinggi. Instrumen properti tidak sama dengan umumnya instrumen investasi lain yang mudah dipengaruhi oleh faktor eksternal. Harga rumah tentu berubah, namun butuh periode tahunan. Sebaliknya, harga-harga di bursa saham sangat mungkin berfluktuasi dengan cepat karena isu ekonomi, politik dan keamanan dalam negeri (Kellen, 2011).

Krisis keuangan yang dialami dunia pada akhir tahun 2007 dipicu oleh bangkrutnya perusahaan-perusahaan pengembang atau real estate, dan bank-bank yang mendanai kredit perumahan di Amerika Serikat, yang dikenal dengan peristiwa subprime mortgage loan. Krisis yang terjadi membuat manajemen perusahaan diseluruh dunia harus cepat merubah keputusankeputusan keuangan terutama keputusan pendanaan dan investasi agar dapat mencapai tujuannya sehingga dapat bertahan hidup (Kellen, 2011). Survey mengenai properti yang dilakukan oleh Ghandayarini \& Lukita (2009, dalam Kellen, 2011) menunjukkan bahwa krisis perekonomian yang melanda dunia sejak tahun 2008 mempengaruhi melambatnya pertumbuhan pasar properti. Hal itu dipengaruhi oleh melemahnya pasar, penurunan aktivitas pengembang, dan kesulitan pendanaan dari perbankan. Melihat siklus perkembangan beberapa produk properti saat ini, dapat diperkirakan arah perkembangannya kedepan lebih positif. Perkembangan tersebut berdampak pada tingginya persaingan antar perusahaan properti dan real estate. Persaingan yang tinggi akan mengakibatkan semakin tinggi pula biaya yang dikeluarkan perusahaan tersebut. Apabila perusahaan tersebut kalah dalam persaingan, maka perusahaan tersebut akan mengalami kerugian yang pada akhirnya akan memperngaruhi keuangan perusahaan, sehingga menyebabkan perusahaan tersebut mengalami financial distress (Aisyah, 2013).

Salah satu upaya yang dapat ditempuh dalam mewujudkan GCG dalam pengelolaan korporasi adalah dengan membentuk komisaris independen yang duduk dalam jajaran pengurus perseroan serta Komite Audit . Keberadaan komisaris independen dan Komite audit diharapkan dapat bersikap netral terhadap segala kebijakan yang dibuat oleh direksi, karena keberadaan GCG saat ini bukan hanya menjadi kewajiban bagi setiap perusahaan tetapi telah menjadi sebuah kebutuhan yang menjembatani hubungan antara investor dengan manajemen perusahaan (agency theory). Struktur kepemilikan menjadi penting dalam teori keagenan karena 
sebagian besar argumentasi konflik keagenan disebabkan oleh adanya pemisahan kepemilikan dan pengelolaan. Menarik untuk diketahui pengaruh GCG dan struktur kepemilikan terhadap kinerja keuangan perusahaan, karena kinerja keuangan merupakan ukuran keberhasilan perusahaan menunjukkan kemampuan dalam mencapai tujuan dan sasaran. Kinerja keuangan perusahaan juga menjadi acuan dari nilai suatu perusahaan yang berpengaruh terhadap ketertarikan investor berinvestasi. Menurut Munawir (2007) pengukuran kinerja merupakan alat analisis data serta pengendalian bagi perusahaan.

\section{Tujuan Penelitian}

Tujuan dalam penelitian ini adalah untuk menguji dan menjelaskan pengaruh proporsi dewan komisaris independen, Kepemilikan Manajerial dan kepemilikan institusional terhadap ROE dan ROA.

\section{KAJIAN TEORI}

\section{Corporate Governance}

Istilah corporate governance dapat didefinisikan dari berbagai disiplin ilmu seperti ilmu hukum, psikologi, ekonomi, manajemen, keuangan, akuntansi, filsafat bahkan dalam disiplin ilmu agama. Oleh karena itu, seringkali dapat dilihat definisi corporate governance secara berbeda. Jadi corporate governance adalah suatu sistem yang menjembatani kepentingan pihak internal dengan pihak eksternal untuk menghindari terjadinya konflik keagenan, sehingga dapat mencapai tujuan perusahaan dan meningkatkan nilai perusahaan.

\section{Agency Theory}

Agency theory terbentuk berdasarkan hubungan kontrak antar anggota-anggota dalam perusahaan, dimana principal dan agen sebagai pelaku utama. Perbedaan kepentingan yang terjadi dalam suatu kontrak kerja, akan memunculkan suatu konflik yang disebut sebagai konflik keagenan.

\section{Stakeholder Theory}

Pada awalnya teori agensi hanya diterapkan pada hubungan antara pemilik saham dan pihak manajemen. Namun pada perkembangan riset selanjutnya menunjukkan bahwa pihak yang memiliki kepentingan terhadap perusahaan tidak hanya pemegang saham, termasuk didalamnya adalah karyawan, kreditor, pemerintah, dan pihak lain yang terlibat (Sanda et al., 2005).

John \& Senbet (1998, dalam Sanda et al., 2005) membuat penelitian tentang stakeholder theory yang berfokus pada mekanisme GCG. Peneliti menyatakan bahwa terdapat banyak kepentingan yang berbeda dari banyak kalangan terhadap operasional suatu perusahaan. Seperti contohnya, apabila perusahaan hendak melakukan suatu investasi yang berisiko tinggi, maka kemungkinan besar kreditor akan menolak investasi tersebut, meskipun pemegang saham akan mendukung pengambilan kredit, karena dapat memberikan return yang tinggi bagi para pemegang saham.

\section{Prinsip Corporate Governance}

Dalam penerapan Corporate Governance terdapat beberapa prinsip yang perlu diperhatikan oleh perusahaan untuk diterapkan pada kegiatan bisnis dalam perusahaan. Terdapat lima prinsip yang dijadikan pedoman perusahaan dalam menjalankan bisnis dan meningkatkan kemakmuran, yakni Transparency, Accountability, Responsibility, Indepandency, dan Fairness. Prinsip ini diuraikan seperti dalam Peraturan Menteri BUMN Nomor : PER-01/MBU/2011.

\section{Transparency (Keterbukaan)}

Prinsip transparansi, yaitu keterbukaan dalam melakukan proses pengambilan keputusan dan keterbukaan dalam mengungkapkan informasi material dan relevan mengenai perusahaan. Prinsip keterbukaan ini sangat penting dalam penerapan good corporate governance. Keterbukaan yang memadai diperlukan investor dalam kemampuannya untuk mengambil keputusan terhadap resiko dan keuntungan investasinya. Kurangnya informasi dan tidak adanya keterbukaan dalam sebuah perusahaan, akan membatasi investor untuk memperkirakan nilai resiko ataupun keuntungan dari perubahan modal.

Keterbukaan perusahaan dalam mengungkapkan informasi kepada masyarakat akan memberikan dampak positif bagi perusahaan, dimana masyarakat akan mampu menilai suatu kinerja perusahaan yang kemudian akan memberikan suatu kepercayaan terhadap suatu perusahaan apabila kinerja perusahaan 
tersebut dinilai baik.

\section{Accountability (Akuntabilitas)}

Prinsip akuntabilitas yaitu kejelasan fungsi pelaksanaan dan pertanggungjawaban organ perusahaan sehingga pengelolaan terlaksana secara efektif. Prinsip akuntabilitas menurut Arifin (2005:14) berhubungan dengan adanya sistem yang mengendalikan hubungan antara unitunit pengawasan yang ada di perusahaan. Prinsip ini memberikan jaminan untuk dapat menunjukan pelaksanaan dan pembatasan kekuasaan yang jelas yang dibebankan pada suatu fungsi. Penerapan prinsip akuntabilitas harus dikelola dengan baik, namun tetap memperhitungkan kepentingan pemegang saham dan pemangku kepentingan yang lain sehingga kinerja yang berkesinmabungan akan tercapai dengan baik.

\section{Responsibility (Pertanggung jawaban)}

Prinsip pertanggungjawaban merupakan kesesuaian di dalam pengelolaan perusahaan terhadap peraturan perundang-undangan dan prinsip-prinsip korporasi yang sehat. Bentuk pertanggungjawaban perusahaan adalah kepatuhan perusahaan terhadap peraturan yang berlaku. Penerapan prinsip ini diharapkan dapat menyadarkan perusahaan bahwa dalam kegiatan operasionalnya, perusahaan juga mempunyai tanggung jawab kepada stakeholders lainnya.

\section{Independency (Kemandirian)}

Prinsip Kemandirian merupakan keadaan dimana perusahaan dikelola secara profesional tanpa benturan kepentingan dan pengaruh/tekanan dari pihak manapun yang tidak sesuai dengan peraturan perundang-undangan dan prinsipprinsip korporasi yang sehat. Prinsip ini mensyaratkan perusahaan dikelola secara professional, dan prinsip pertanggungjawaban dapat dilaksanakan dengan baik sehingga terhindar dari benturan kepentingan dan tekanan dari pihak luar yang tidak sesuai dengan peraturan yang berlaku. Prinsip kemandirian ini memberikan tanggung jawab bagi masing-masing organ perusahaan untuk mampu mengelola perusahaannya secara mandiri dan tanpa intervensi oleh pihak lain.

\section{Fairness (Kewajaran)}

Prinsip kewajaran merupakan keadilan dan kesetaraan di dalam memenuhi hak-hak pemangku kepentingan (stakeholders) yang timbul berdasarkan perjanjian dan peraturan perundang-undangan. Prinsip ini menuntut adanya suatu perlakuan yang adil dalam memenuhi hak stakeholder sesuai dengan peraturan yang berlaku. Dengan menerapkan prinsip kewajaran diharapkan akan membantu mengurangi konflik yang mungkin akan terjadi dalam suatu organ perusahaan.

\section{Tujuan dan Manfaat Corporate Governance}

Dalam suatu perusahaan, penerapan prinsip GCG diperlukan dalam setiap kegiatan bisnis. Salah satu tujuannya adalah untuk membantu dalam mencapai tujuan. Menurut Forum Corporate Governance in Indonesia (FCGI) beberapa manfaat yang dapat diperoleh dari penerapan Corporate Governance yang baik, antara lain:

a) Meningkatkan kinerja perusahaan melalui proses terciptanya pengambilan keputusan yang lebih baik, meningkatkan efisiensi operasional perusahaan serta lebih meningkatkan pelayanan kepada stakeholder.

b) Mempermudah diperolehnya dana pembiayaan (karena faktor kepercayaan) yang pada akhirnya akan meningkatkan corporate value.

c) Mengembalikan kepercayaan investor untuk menanamkan modalnya di Indonesia.

d) Pemegang saham akan merasa puas dengan kinerja perusahaan, karena sekaligus akan meningkatkan stakeholder value dan deviden. Khusus bagi BUMN akan membantu penerimaan bagi APBN terutama dari hasil privatisasi.

\section{Struktur Kepemilikan}

Struktur kepemilikan yang dipresentasikan sejak tahun 1969 oleh Berle \& Means telah menjadi topik utama dari teori perusahaan modern yang kemudian dikembangkan lebih lanjut oleh Jensen \& Meckling (1976). Struktur kepemilikan dapat dijelaskan dari dua sudut pandang yaitu pendekatan keagenan (agency approach) dan pendekatan ketidakseimbangan informasi (asymmetric information approach). Pendekatan keagenan menganggap struktur 
kepemilikan sebagai suatu instrumen atau alat untuk mengurangi konflik kepentingan. Pendekatan keseimbangan informasi memandang mekanisme struktur kepemilikan sebagai suatu cara untuk mengurangi ketidakseimbangan informasi antara insider dan outsider melalui pengungkapan informasi di pasar modal. Jensen \& Meckling menunjukkan bahwa struktur kepemilikan dapat digunakan untuk mengurangi agency cost yang bersumber dari agency problem. Struktur kepemilikan (kepemilikan manajerial dan kepemilikan institusional) akan menyelaraskan kepentingan manajemen dan pemegang saham.

\section{Kepemilikan Institusional}

Kepemilikan institusional adalah kepemilikan saham perusahaan yang dimiliki oleh institusi atau lembaga seperti perusahaan asuransi, bank, perusahaan investasi dan kepemilikan institusi lain (Wahidahwati, 2002). Alasan pemilihan kepemilikan institusional sebagai proxy struktur kepemilikan, karena institusi memiliki sumber daya yang lebih besar dibandingkan dengan pemegang saham lainnya, sehingga dapat menguasai mayoritas saham. Konsentrasi kepemilikan dianggap memiliki kekuatan untuk mengendalikan keputusan manajemen

\section{Kepemilikan Manajerial}

Berdasarkan teori keagenan, perbedaan kepentingan antara manajer dan pemegang saham ini mengakibatkan timbulnya konflik yang biasa disebut agency conflict. Konflik kepentingan yang sangat potensial ini menyebabkan pentingnya suatu mekanisme yang diterapkan guna melindungi kepentingan pemegang saham (Jensen dan Meckling, 1976).

Menurut Jensen (1993), hipotesis pemusatan kepemimpinan (convergence of interest hypotesis) menyatakan bahwa kepemilikan saham manajerial dapat membantu penyatuan kepentingan antara pemegang saham dengan manajer. Semakin meningkat proporsi kepemilikan saham manajerial maka semakin baik kinerja perusahaan.

\section{Kinerja Keuangan Perusahaan}

Menurut Zarkasyi (2008:48), kinerja merupakan hasil kerja yang dicapai dari suatu usaha organisasi dalam periode tertentu dengan mengacu pada standar yang ditetapkan. Untuk mengetahui apakah suatu perusahaan telah menjalankan kegiatan operasionalnya sesuai dengan rencana yang telah ditetapkan, dan sesuai dengan tujuannya adalah dengan mengetahui kinerja keuangan dari suatu perusahaan tersebut. Kinerja keuangan merupakan salah satu alat ukur yang digunakan untuk mengukur suatu kualitas perusahaan. Kinerja keuangan perusahaan dapat dilihat dan diukur dengan menganalisis suatu laporan keuangan perusahaan.

Berdasarkan uraian pada tinjauan teoritis, maka model penelitian dapat di gambarkan sebagai berikut :

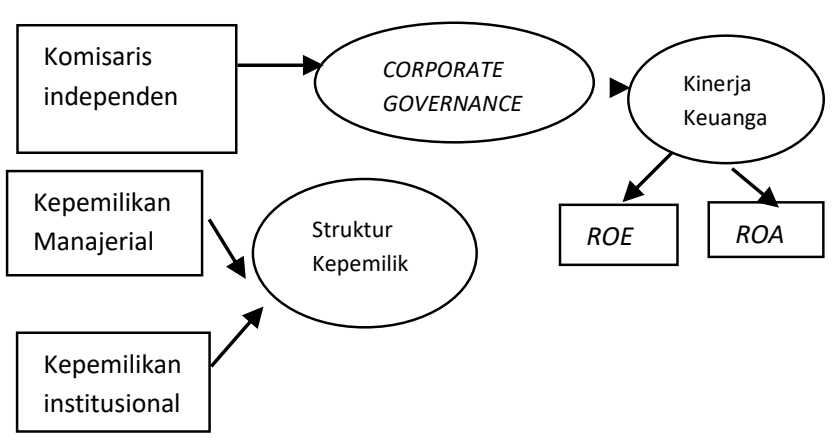

Gambar 1: Model Konsep

\section{METODE PENELITIAN \\ Jenis Penelitian.}

Penelitian ini tergolong pada explanatory research, karena penelitian ini dilakukan untuk menjelaskan pengaruh Corporate Governance dan Struktur kepemilikan terhadap kinerja keuangan Perusahaan.

\section{Variabel Penelitian.}

Variabel yang digunakan dalam penelitian ini terdiri dari variabel independen, yaitu Corporate Governance terdiri dari Proporsi dewan komisaris independen sedangkan Struktur Kepemilikan yang terdiri dari Kepemilikan manajerial dan Kepemilikan institusional . dan variabel dependen kinerja keuangan terdiri dari ROE (return on equity), dan ROA (return on assets).

\section{Populasi dan Sampel}

Populasi adalah wilayah generalisasi yang terdiri atas obyek atau subyek yang mempunyai 
kualitas dan karakteristik tertentu yang ditetapkan oleh peneliti untuk dipelajari, kemudian ditarik kesimpulannya (Sugiyono, 2012:215). Populasi pada penelitian ini adalah perusahaan properti dan real estate yang terdaftar di BEI tahun 2011 2015. Sampel dalam penelitian ini diambil dengan menggunakan metode purposive sampling diperoleh 22 Perusahaan.

\section{Analisis Data}

Metode analisis data yang dipergunakan dalam penelitian ini adalah dengan menggunakan metode analisis kuantitatif dengan menggunakan a) statistik deskriptif ,b) Uji Asumsi Klasik meliputi Uji Normalitas, Uji Multikolinearitas , Uji Autokorelasi, Uji Heteroskedastisitas dan c) statistik Inferensial dengan Uji Hipotesis dengan Analisis Regresi.

\section{HASIL PENELITIAN}

Hasil penelitian memuat data kuantitatif mengenai semua indikator penelitian sesuai kerangka konsep dan hasil uji statistik.

\section{Statistik Deskriptif}

Data-data yang digunakan dalam penelitian ini adalah proporsi dewan komisaris independen (PDKI), kepemilikan institusional (KI), kepemilikan manajerial (KM), dan Return on Equity (ROE), serta Return on Assets (ROA) pada perusahaan properti dan real estate yang terdaftar di BEI selama tahun 2011-2015. Dalam statistik deskriptif disajikan data dari masing-masing variabel yang digunakan,

1. PDKI (proporsi dewan komisaris independen) memiliki nilai rata-rata sebesar 40,9\%. Hal itu menunjukkan bahwa rata-rata perusahaan properti dan real estate yang terdaftar di BEI telah memenuhi peraturan mengenai kewajiban bagi perusahaan yang sahamnya tercatat di BEI untuk memiliki komisaris independen sekurang-kurangnya tiga puluh persen dari jajaran anggota dewan komisaris.

2. Rata-rata KI (kepemilikan institusional) dalam Tabel 4.1 menunjukkan bahwa jumlah kepemilikan saham institusional pada perusahaan adalah sebesar $66,58 \%$ dari total saham beredar. Nilai maksimum kepemilikan institusional yang mencapai $95 \%$ dan nilai rata-rata yang tinggi, menunjukkan bahwa rata-rata saham perusahaan properti dan real estate yang terdaftar di BEI didominasi oleh pemegang saham institusional, sehingga para institusi berada di posisi utama untuk memonitor manajemen perusahaan. Standar deviasi yang tinggi menunjukkan bahwa jumlah kepemilikan intitusional pada perusahaan properti dan real estate berbeda-beda sehingga titik data menyebar pada beberapa nilai.

3. Rata-rata KM (kepemilikan manajerial) pada perusahaan sampel penelitian hanya sebesar $0,41 \%$ dari total saham beredar. Jumlah ratarata kepemilikan saham manejerial yang terbilang kecil, menunjukkan bahwa perusahaan properti dan real estate yang terdaftar di BEI belum menerapkan teori keagenan yang dikemukakan oleh Jensen dan Meckling (1976), karena perusahaan belum meningkatkan kepemilikan manajerial yang dianggap sebagai mekanisme kontrol yang tepat dalam mengurangi konflik keagenan yang terjadi. Standar deviasi yang rendah menunjukkan bahwa jumlah kepemilikan manajerial pada perusahaan properti dan real estate tidak jauh berbeda, sehingga titik data cenderung dekat.

4. ROE (return on equity) memiliki nilai tertinggi sebesar 33,20 dan rata-rata saham mampu menghasilkan prosentase laba bersih terhadap ekuitas sebesar 10,67\%. Nilai yang cukup tinggi menunjukkan bahwa perusahaan properti dan real estate cukup baik dalam menggunakan dana investasi dalam menghasilkan pertumbuhan laba.

5. Rata-rata ROA (return on asset) memiliki nilai rata-rata sebesar $4,92 \%$. Hal ini berarti bahwa rata-rata saham, mampu menghasilkan prosentase laba bersih terhadap asset sebesar $4,92 \%$. Nilai yang kecil dapat diartikan bahwa perusahaan properti dan real estate yang terdaftar di BEI kurang efisien dalam penggunaan modal yang berasal dari aktiva dalam perusahaan tersebut.

\section{Uji Asumsi Klasik \\ Hasil Uji Normalitas}

Hasil uji normalitas, diperoleh nilai sig > 0,05 yang berarti bahwa model regresi yang 
digunakan dalam penelitian ini berdistribusi normal.

\section{Hasil Uji Multikolinieritas}

Berdasarkan nilai VIF dari PDKI (1.047), KI (1.016) dan KM (1.032) kurang dari 10 dan nilai tolerance mendekati 1 yaitu PDKI $(0,959)$, KI $(0,985)$ dan KM $(0,969)$. Oleh karena itu, dapat disimpulkan bahwa tidak terdapat korelasi antara variabel bebas yang satu dengan variabel bebas yang lain dalam model regresi.

\section{Hasil Uji Autokorelasi}

Hasil nilai Durbin Watson terletak antara batas atas atau upper bound (du) dan (4-du), maka koefisien autokorelasi sama dengan nol yang berarti bahwa tidak terjadi autokorelasi dalam variabel yang digunakan dalam model penelitian.

\section{Hasil Uji Heterokedastisitas}

Hasil scatterplot pada Gambar 4.1 dan 4.2 terlihat titik-titik tersebar secara acak (tak berpola) baik di atas maupun di bawah angka 0 pada sumbu ROE dan ROA, sehingga disimpulkan tidak terjadi heteroskedastisitas (asumsi homoskedastisitas terpenuhi).

\section{Statistik Inferensial}

Uji hipotesis dilakukan dengan meregresikan setiap variabel independen dengan variabel dependennya, dengan menggunakan teknik analisis regresi linier berganda. Peneliti menggunakan $\alpha=5 \%$ untuk menilai signifikansi hubungan antara setiap variabel yang diteliti.

Hasil analisis pengaruh Proporsi Dewan Komisaris Independen, Kepemilikan Institusional, Kepemilikan Manajerial terhadap Return on Equity (ROE).

Dalam pengolahan data dengan menggunakan analisis regresi linier berganda, dilakukan beberapa tahapan untuk mencari pengaruh antara variabel independen dan dependen. Berdasarkan hasil pengolahan data didapatkan ringkasan seperti berikut:
Tabel 1. Hasil Analisis Regresi Variabel PDKI, KI, dan KM terhadap ROE

\begin{tabular}{|c|c|c|c|c|}
\hline Variabel & $\boldsymbol{B}$ & $\mathbf{t}_{\text {hitung }}$ & Signifikansi & Ket. \\
\hline Konstanta & 2.066 & & & \\
\hline PDKI & $\overline{-}-017$ & $\begin{array}{l}- \\
5.379\end{array}$ & 0.000 & Signifikan \\
\hline KI & $\begin{array}{l}- \\
0.007\end{array}$ & - & 0.000 & Signifikan \\
\hline KM & 0.018 & 0.544 & 0.587 & $\begin{array}{l}\text { Tidak } \\
\text { Signifikan }\end{array}$ \\
\hline \multicolumn{2}{|l|}{ A } & \multicolumn{3}{|c|}{$=0.050$} \\
\hline \multicolumn{2}{|l|}{$\mathrm{R}$} & \multicolumn{3}{|c|}{$=0.538$} \\
\hline \multicolumn{2}{|c|}{$\begin{array}{l}\text { Koefisien } \\
\text { Determinasi (Adj. } \\
\mathrm{R}^{2} \text { ) }\end{array}$} & \multicolumn{3}{|c|}{$=0.269$} \\
\hline \multicolumn{2}{|l|}{ F-hitung } & \multicolumn{3}{|c|}{$=14.358$} \\
\hline \multicolumn{2}{|c|}{ F-tabel $\left(F_{3,106,0.05}\right)$} & \multicolumn{3}{|c|}{$=2.690$} \\
\hline \multicolumn{2}{|l|}{ Signifikansi } & \multicolumn{3}{|c|}{$=0.000$} \\
\hline \multicolumn{2}{|c|}{$\mathrm{t}$-tabel $\left(\mathrm{t}_{106,0.05}\right)$} & \multicolumn{3}{|c|}{$=1.983$} \\
\hline
\end{tabular}

Hasil analisis regresi tersebut menunjukkan bahwa variabel independen proporsi dewan komisaris independen (PDKI) dan kepemilikan institusional (KI) memiliki pengaruh negatif terhadap variabel dependen Return on Equity (ROE). Dapat dilihat bahwa koefisien yang diperoleh variabel PDKI dan KI bernilai negatif, yang berarti bahwa variabel independen PDKI dan KI berbanding terbalik dengan variabel dependen ROE. Apabila terjadi peningkatan pada PDKI dan $\mathrm{KI}$, maka ROE akan menurun dan sebaliknya apabila PDKI dan KI menurun, maka akan terjadi peningkatan pada ROE.

Hasil yang berbeda didapatkan pada variabel independen kepemilikan manajerial (KM) yang berpengaruh tidak signifikan terhadap variabel dependen Return on Equity (ROE). Koefisien yang didapatkan bernilai positif berarti bahwa KM berbanding lurus terhadap ROE. Apabila terjadi peningkatan pada KM, maka ROE akan meningkat dan sebaliknya apabila KM menurun, maka akan terjadi penurunan pada ROE.

Berdasarkan hasil tersebut juga diketahui bahwa nilai koefisien determinasi (Adjusted $R$ Square) sebesar 0.269. Hasil tersebut menunjukkan bahwa kontribusi dari variabelvariabel bebas (PDKI, KI, dan KM) yang disertakan dalam persamaan regresi terhadap ROE, adalah sebesar $26.9 \%$. Hal itu menunjukkan bahwa kontribusi sebesar $73.1 \%$ disumbangkan oleh 
variabel lainnya yang tidak dimasukkan ke dalam persamaan ini.

Hasil analisis pengaruh Proporsi Dewan Komisaris Independen, Kepemilikan Institusional, Kepemilikan Manajerial terhadap Return on Asset (ROA).

Dalam pengolahan data dengan menggunakan analisis regresi linier berganda, dilakukan beberapa tahapan untuk mencari hubungan antara variabel independen dan dependen. Berdasarkan hasil pengolahan data didapatkan ringkasan seperti berikut:

Tabel 2. Hasil Analisis Regresi Variabel PDKI, KI, dan KM terhadap ROA

\begin{tabular}{|l|l|l|l|l|}
\hline Variabel & \multicolumn{1}{|c|}{$\boldsymbol{B}$} & $\mathbf{t}_{\text {hitung }}$ & $\begin{array}{l}\text { Signifi } \\
\text { kansi }\end{array}$ & \multicolumn{1}{|c|}{ Ket. } \\
\hline Konstanta & -1.531 & & & \\
\hline PDKI & 0.074 & 2.463 & 0.015 & Signifikan \\
\hline KI & 0.047 & 2.914 & 0.004 & Signifikan \\
\hline KM & 0.799 & 2.649 & 0.009 & Signifikan \\
\hline A & $=0.050$ & \\
\hline R & $=0.383$ \\
\hline $\begin{array}{l}\text { Koefisien Determinasi } \\
\left.\text { Adj. }{ }^{2}\right)\end{array}$ & $=0.122$ \\
\hline F-hitung & $=6.071$ \\
\hline F-tabel $\left(\mathrm{F}_{3,106,0.05}\right)$ & $=2.690$ \\
\hline Signifikansi & $=0.001$ \\
\hline t-tabel $\left(\mathrm{t}_{106,0.05}\right)$ & $=1.983$ \\
\hline
\end{tabular}

Hasil analisis regresi menunjukkan bahwa ketiga variabel independen, yaitu proporsi dewan komisaris independen (PDKI), kepemilikan institusional (KI), dan kepemilikan manajerial (KM) memiliki pengaruh positif signifikan terhadap variabel dependen Return on Assets (ROA). Koefisien yang bernilai positif dari ketiga variabel independen berarti bahwa terdapat hubungan yang berbanding lurus antara PDKI, KI dan KM terhadap variabel dependen ROA. Apabila terjadi peningkatan pada PDKI, KI dan KM maka ROA akan meningkat dan sebaliknya apabila menurun, maka akan terjadi penurunan pada ROA. Nilai signifikansi yang menunjukkan angka kurang dari $\alpha=0.050$ dan thitung lebih besar dari t tabel, menunjukkan bahwa pengaruh dari ketiga variabel tersebut signifikan. Dalam analisis data tersebut juga didapatkan nilai koefisien determinasi (Adjusted $R$ Square) sebesar 0.122. Hasil tersebut menjelaskan bahwa kontribusi dari variabel-variabel bebas (PDKI, KI, dan KM) yang disertakan dalam persamaan regresi terhadap ROA adalah sebesar $12.2 \%$, sedangkan kontribusi lain sebesar $87.8 \%$ disumbangkan oleh variabel lainnya yang tidak dimasukkan ke dalam persamaan ini.

\section{Pembahasan}

Setelah mengetahui hasil analisis regresi atas pengaruh variabel independen terhadap variabel dependen yang digunakan dalam penelitian ini, selanjutnya akan dibahas mengenai kesesuaian hasil analisis terhadap teori-teori yang digunakan dan perbandingan terhadap penelitian yang telah dilakukan oleh peneliti sebelumnya.

\section{Pengaruh Proporsi Dewan Komisaris Independen, Kepemilikan Intitusional, dan Kepemilikan Manajerial terhadap Return on Equity (ROE)}

Hasil analisis regresi membuktikan bahwa proporsi dewan komisaris independen (PDKI) memiliki pengaruh negatif terhadap kinerja keuangan perusahaan yang diwakili oleh Return on Equity (ROE). Hasil ini menunjukkan bahwa hipotesis yang diajukan ditolak dan tidak didukung oleh teori yang digunakan. Pengaruh negatif dari dewan komisaris independen dikarenakan pengawasan oleh komisaris pada perusahaan di Indonesia yang belum sepenuhnya independen. Dalam penelitian ini terdapat beberapa perusahaan properti dan real estate yang terdaftar di BEI yang memiliki komisaris independen dengan masa kerja lebih dari satu periode. Hal itu dapat menjadi penyebab menurunnya kinerja perusahaan, karena independensi dari komisaris independen menjadi diragukan.. Komisaris independen tidak boleh memiliki hubungan bisnis dengan perusahaan, kecuali gaji atau fee yang diterimanya dari perusahaan. Komisaris independen sebaiknya bukan mantan direktur atau komisaris perusahaan di periode sebelumnya. Mereka juga tidak boleh terlalu lama menjabat sebagai komisaris independen, yaitu maksimum satu periode masa kerja saja.

Dalam penelitian ini juga diperoleh hasil bahwa kepemilikan institusional (KI) berpengaruh secara negatif terhadap ROE. Beberapa hal yang dirasa merupakan penyebab pengaruh negatif tersebut adalah dikarenakan kepemilikan saham institusi pada perusahaan properti dan real estate yang terkonsentrasi (consentration of ownership) 
sehingga memungkinkan terjadinya hubungan afiliasi antara pemilik, pengawas, dan direktur perusahaan. Hal itu juga terjadi dalam perusahaan yang dijadikan sampel penelitian, sehingga sebaiknya dilakukan pembenahan atas kondisikondisi yang saat ini terjadi dalam rangka penerapan corporate governance.

Kepemilikan institusional yang terkonsentrasi juga akan menimbulkan konflik keagenan tipe II, yaitu konflik yang terjadi antara pemegang saham mayoritas dan minoritas karena manajer akan cenderung bertindak sesuai dengan desakan pemegang saham mayoritas. Hasil yang berbeda didapatkan dari variabel Kepemilikan manajerial (KM) yang memiliki pengaruh positif yang tidak signifikan terhadap ROE. Jumlah rata-rata kepemilikan manajerial yang masih relatif kecil membuat manajer lebih banyak dikendalikan oleh pemilik mayoritas, sehingga manajer hanya sebagai kepanjangan tangan pemilik mayoritas. Selain itu, manajer memang memiliki kewajiban untuk memaksimumkan kesejahteraan pemegang saham.

\section{Pengaruh Proporsi Dewan Komisaris Independen, Kepemilikan Intitusional, dan Kepemilikan Manajerial terhadap Return on Asset (ROA)}

Hasil analisis regresi membuktikan bahwa seluruh variabel independen yang digunakan yaitu proporsi dewan komisaris independen (PDKI), kepemilikan institusional (KI) dan kepemilikan manajerial (KM) memiliki pengaruh yang positif dan signifikan terhadap variabel kinerja keuangan perusahaan yang diwakili oleh variabel Return on Assets (ROA).

Hasil positif signifikan atas pengaruh komisaris independen terhadap ROA ini mendukung teori keagenan yang dikemukakan oleh Jensen dan Meckling (1976) bahwa komisaris independen dibutuhkan pada jajaran dewan komisaris untuk mengawasi dan mengontrol tindakan-tindakan direksi sehubungan dengan perilaku oportunistik mereka. Dibutuhkan seperangkat peraturan yang mengatur tata kelola perusahaan antar pihak-pihak yang berkepentingan sehingga tujuan umum perusahaan dapat tercapai, salah satunya adalah dengan menunjuk komisaris independen. Komisaris independen adalah komisaris yang bukan merupakan anggota manajemen, pemegang saham mayoritas, pejabat atau dengan cara lain yang berhubungan langsung atau tidak langsung dengan pemegang saham mayoritas dari suatu perusahaan yang mengawasi pengelolaan perusahaan.

Penelitian ini menunjukkan bahwa Good Corporate Governance (GCG) berpengaruh positif signifikan terhadap ROA. Hal ini membuktikan bahwa perusahaan yang sudah menerapkan GCG dengan baik dan secara berkesinambungan akan mampu memberikan keuntungan kepada perusahaan dengan memanfaatkan aktiva yang telah dikeluarkan oleh perusahaan terlebih lagi aset merupakan operasional utama bagi perusahaan properti dan real estate. Kepemilikan Institusional (KI) juga memiliki pengaruh positif signifikan terhadap kinerja perusahaan yang diukur menggunakan ROA. Kepemilikan suatu institusi dalam suatu entitas bisnis akan meningkatkan pengawasan yang akan dilakukan terhadap entitas bisnis tersebut. Hal ini dikarenakan sebuah institusi akan menjaga dan mengawasi investasinya dengan baik, karena memiliki kepentingan besar terhadap investasinya. Dengan demikian maka akan terjadi peningkatan atas pengendalian terhadap kebijakan-kebijakan manajemen, yang pada akhirnya akan meningkatkan kinerja manajemen. Berdasarkan hasil pada penelitian ini, perusahaan sampel mayoritas dimiliki oleh kepemilikan institusional. Kepemilikan institusional yang meningkat akan meningkatkan kinerja keuangan yang diukur dengan ROA..

Hasil penelitian ini sejalan dengan teori yang dikemukakan Jensen dan Meckling (1976) yang menyatakan bahwa kepemilikan institusional memiliki peranan yang sangat penting dalam meminimalisasi konflik keagenan yang terjadi antara manajer dan pemegang saham. Keberadaan investor institusional dianggap mampu menjadi mekanisme monitoring yang efektif dalam setiap keputusan yang diambil oleh manajer. Peningkatan kepemilikan institusional menyebabkan kinerja manajemen diawasi secara optimal sehingga manajemen menghindari perilaku yang merugikan prinsipal.

Dengan hasil penelitian yang menunjukkan bahwa kepemilikan saham oleh institusional memberikan pengaruh yang positif dan signifikan terhadap ROA, dapat disimpulkan bahwa suatu perusahaan dengan kepemilikan saham oleh institusional yang besar mampu memberikan suatu 
pengawasan atas aktiva yang telah dikeluarkan perusahaan, dan keuntungan yang didapatkan akan lebih terkontrol. Besar kecilnya jumlah kepemilikan saham manajerial dalam perusahaan dapat mengindikasikan adanya kesamaan (congruence) kepentingan antara manajemen dengan pemegang saham. Perusahaan dengan jumlah kepemilikan saham manajerial yang semakin besar seharusnya mempunyai konflik keagenan yang rendah dan biaya keagenan yang rendah pula.

\section{KESIMPULAN DAN SARAN Kesimpulan}

Penelitian ini bertujuan untuk mengetahui pengaruh Corporate Governance (CG) dan struktrur kepemilikan terhadap kinerja keuangan perusahaan Corporate Governance diproksikan dengan proporsi dewan komisaris independen, struktur kepemilikan diproksikan dengan kepemilikan institusional, dan kepemilikan manajerial. Sedangkan kinerja keuangan perusahaan diukur dengan rasio profitabilitas Return on Equity (ROE) dan Return on Asset (ROA).

Hasil penelitian menunjukkan bahwa proporsi dewan komisaris independen dan kepemilikan institusional, berpengaruh negatif dan signifikan terhadap ROE. Keberadaan komisaris independen diharapkan bukan hanya sekedar formalitas dan pemenuhan peraturan dari BEI yang mewajibkan tiap perusahaan memiliki sekurang-kurangnya $30 \%$ komisaris independen dari total dewan komisaris . Sebaiknya komisaris independen dalam jajaran perusahaan dapat berperan aktif, independen, dan konstruktif sehingga dapat memonitoring aktivitas perusahaan agar dapat meningkatkan kinerja.

Kepemilikan saham institusi pada perusahaan properti dan real estate yang terkonsentrasi (concentration of ownership) memungkinkan terjadinya hubungan afiliasi antara pemilik, pengawas, dan direktur perusahaan . Hasil yang berbeda didapatkan dari variabel kepemilikan manajerial (KM) yang memiliki pengaruh positif tidak signifikan terhadap ROE. Jumlah rata-rata kepemilikan manajerial yang masih relatif kecil membuat manajer lebih banyak dikendalikan oleh pemilik mayoritas, sehingga manajer hanya sebagai kepanjangan tangan pemilik mayoritas.
Hasil lain pada penelitian ini menunjukkan bahwa GCG dan struktur kepemilikan memiliki pengaruh yang positif dan signifikan terhadap kinerja keuangan perusahaan yang dihitung dengan Return on Asset (ROA). Selain itu, hasil yang menunjukkan bahwa Good Corporate Governance (GCG) dan struktur kepemilikan berpengaruh positif signifikan terhadap ROA, membuktikan bahwa perusahaan yang sudah menerapkan GCG dengan baik dan secara berkesinambungan, akan mampu memberikan keuntungan kepada perusahaan dengan memanfaatkan aktiva yang telah dikelola oleh perusahaan. Terlebih lagi, aset merupakan modal operasional utama bagi perusahaan properti dan real estate .

\section{Saran}

Berdasarkan hasil kesimpulan dari penelitian, maka diajukan beberapa saran sebagai berikut:

Bagi Perusahaan

Perusahaan sebaiknya dapat menjadikan corporate governance sebagai corporate culture sehingga penerapan prinsip-prinsip GCG yang dilakukan tidak semata hanya memenuhi peraturan, tetapi juga dapat meningkatkan kinerja perusahaan secara keseluruhan.

Bagi Peneliti Selanjutnya Peneliti selanjutnya disarankan menambah variabel mekanisme GCG seperti ukuran perusahaan, ukuran dewan direksi, dan aktivitas rapat dewan komisaris yang mungkin lebih berpengaruh terhadap kinerja keuangan perusahaan. Penggunaan variabel dependen yang menggunakan ukuran pasar seperti Tobin's Q perlu digunakan untuk menunjukkan kontribusi yang berbeda.

\section{DAFTAR PUSTAKA}

Ang, James S., Cole, Rebel A., \& Lin, James Wuh. (1999). Agency Costs and Ownership Structure. Journal of Finance. 55, 81-106.

Arifin. (2005). Peran Akuntan Dalam Menegakkan Prinsip Good Corporate Governance Pada Perusahaan di Indonesia (Tinjauan Perspektif Teori Keagenan). Sidang Senat Guru Besar. Universitas Diponegoro Semarang. 1-52. 
Arifin, Helmi. (2010). Hubungan Antara Mekanisme Good Corporate Governace dengan Kinerja Saham. Skripsi. Universitas Diponegoro Semarang.

Berle, Adolf A., \& Means, Gardiner C. (1969). The modern Corporation and Private Property. New Brunswick: Transaction Publishers.

Chen, Jiangou, Blenman, Lloyd, \& Dar-Hsin, Chen. (2008). Does Institutional Ownership create values? The New Zaeland Case. Quarterly Journal of Finance and accounting. 47(4), 109-124.

Colleman, Anthony Kyereboah. (2007). Corporate Governance and Firm Performance in Africa: A Dinamic Panel Data Analysis. A Paper Prepared for The International Conference on Corporate Governance in Emerging Markets. Sabancy University, Istanbul Turkey. 1-32

Demsetz, Harold, \& Villalonga, Bellen. (2001). Ownership Structure and Corporate Performance. Journal of Corporate Finance. 7, 209-233.

Effendi, Arief. (2009). The Power of Good Corporate Governance: Teori dan Implementasi. Jakarta: Salemba Empat.

Fauzi, Fitriya, \& Locke, Stuart. (2012). Board Structure, Ownership Structure and Firm Performance: A Study of New Zealand Listed-Firms. Journal of Accounting and Finance. 8(2), 43-67.

Hastuti, Theresia Dwi. (2005). Hubungan Antara Good Corporate Governance dan Struktur Kepemilikan dengan Kinerja Keuangan. Simposium Nasional Akuntansi VIII. 238247.

Indriantoro, Nur, \& Bambang Soepomo. (2009). Metodologi Penelitian Bisnis Untuk Akuntansi dan Manajemen. Yogyakarta: BPFE-Yogyakarta.

Munawir, S. (2007). Analisis Laporan Keuangan. Yogyakarta: Liberty Yogyakarta.

Sugiyono. (2012). Metode Penelitian Kuantiatif Kualitatif dan $R \& D$. Bandung: Alfabeta.
Zarkasyi, M. Wahyudi. (2008). Good Corporate Governance pada Badan Usaha Manufaktur, Perbankan, dan Jasa Keuangan Lainnya. Bandung: Alfabeta. 